\title{
College English Online Teaching Practice and Reflection During Prevention and Control of COVID-19 Pandemic
}

\author{
Minglan Zhang ${ }^{1,2, *}$ Fa-de Wang ${ }^{1}$ \\ ${ }^{1}$ Faculty of Foreign Languages, Huaiyin Institute of Technology, Huaian, Jiangsu 223003, China \\ ${ }^{2}$ Faculty of Foreign Languages, Huaiyin Institute of Technology, Huaian, Jiangsu 223003, China \\ *Corresponding author. Email: 894899157@qq.com
}

\begin{abstract}
Due to the impact of the Covid-19 pandemic, the Ministry of Education in China issued the guidance of practicing online teaching in colleges and universities at the beginning of 2020, which requires colleges and universities to make full use of online teaching resources, and actively carry out online teaching. Taking college English online teaching of Huaiyin Institute of Technology in Jiangsu Province as an example, this paper summarizes and reflects on its college English online teaching practice, so as to provide reference for online teaching and improve the online teaching quality of college English.
\end{abstract}

Keywords: online teaching, college English, Covid-19 Pandemic

\section{INTRODUCTION}

COVID-19 Pandemic spread throughout the country in the early 2020, all provinces and municipalities started to respond to major public health emergencies. The Ministry of Education in China has organized 22 online course platforms to open more than 24000 online courses free of charge, covering 12 Undergraduate Disciplines and 18 professional categories of higher vocational colleges. And issued the guidance of implementing online teaching and distance education in colleges and universities, which requires colleges and universities to make full use of online teaching resources, and actively carry out online teaching and offline learning with the support of MOOC platform, other experimental resource platform as well as online learning resources on campus to ensure the teaching process and teaching quality, and achieve the goal of "no teaching stop, no class suspension" during the epidemic prevention and control period.[1]

After the initial investigation of the teaching platforms, careful analysis and comparison of the advantages and disadvantages of the resources of each platform, the Faculty of Foreign Languages of Huaiyin Institute of Technology adopts the mode of MOOC plus Dingtalk or Tencent live broadcast to carry out online teaching and flipped classroom teaching. With videos, coursewares, tests and assignments provided by MOOC of China's Universities as the main teaching resources, Dingtalk released supplementary learning resources, arranged learning tasks and after-school guidance, and conducted real-time communication with students.

\section{BEFORE CLASS ONLINE TEACHING AND LEARNING ACTIVITIES}

\subsection{The Setting-up of SPOC Courses on MOOC Platform}

All teachers and students are registered and certified on the MOOC platform of China's Universities. Meanwhile, the teaching management department of the college has established cloud courses on the platform. Taking the College English Viewing, Listening and Speaking course as an example, we adopt the New Horizon College English published by Foreign Language Teaching and Research Press as the source course. Before the class, teachers sort out the autonomous learning content for students' watching and listening. Compared with MOOC, SPOC bears the characteristics of "small scale of students" and "more targeted teaching". The openness and interactivity of SPOC platform can make up for the deficiency of traditional large class teaching. Teachers can solve students' problems in the learning process and avoid the limitation of time and place in traditional classroom. Students can scan the class QR code to join the class created by the teachers. After creating the MOOC class group, teachers can click to enter the classroom for lesson preparation. Teachers can design teaching process according to their own courses and students' characteristics, and create rich and effective classroom tasks, such as discussion, exercise, questionnaire and announcement. The exercises created by each teacher can be sent to the exercise database for resource sharing. 


\subsection{The Setting-up of Class Group on Dingtalk Platform}

Teachers set up teacher-student communication class group on Dingtalk platform, all students join the group to ensure the normal online teaching. Teachers can choose online live broadcast mode or video conference mode according to the smoothness of the network. Online live broadcast can directly generate playback, while video conference requires teachers to record courses manually. Before the start of online teaching, teachers and students should be familiar with the use of platform, know the teaching procedure of online teaching, learn to solve problems in time.

\section{PRACTICE OF COLLEGE ENGLISH ONLINE TEACHING AND LEARNING}

\subsection{Autonomous Learning before Class}

Before the class, all the teachers undertaking the College English teaching uploaded teaching resource package to the platform, including video materials, teaching courseware, teaching PDF documents, audio and video files of MOOC learning, course introduction, teaching content, course progress, reference materials, preview content and expanding resources. Students can log on the network platform, learn about the teaching contents, learning plan, learning objectives, learning key and difficult points, learning tasks and interact with teachers. Students can watch the platform video resources, complete online autonomous learning, and prepare for the oral practice in class, so as to save time for discussion, communication. Also, they can search the Internet or do individual independent thinking to understand the background knowledge and finish the relevant learning tasks .At this stage, students have time to take notes, think about and sort out the key and difficult points. Teachers should give appropriate guidance to help students find and analyze problems, and encourage students to solve problems through online communication and discussion. Therefore, if students encounter the part that they can't understand, they can solve the problem through the Dingtalk platform to initiate group discussion or teacherstudent dialogue, which can change the previous learning habits and students change from passive knowledge receiver to active problem discoverer and solver.[2]

\subsection{In- class Online Teaching and Learning}

Ten minutes before the formal class, teachers should set the schedule and organize the students to sign in; the Dingtalk group regularly reminds the class students to attend class. After the check-in, the teacher starts the live broadcast. According to the video resources watched by the students on the platform in advance, the teacher combs the knowledge points through PPT works, explains the key and difficult points, pays attention to the combination of teaching and practice, uses the platform questioning and discussion functions to interact with students, and mobilizes the enthusiasm of answering questions by students through the forms of connecting microphone, and so on. To ensure the effectiveness online learning, teachers need to clarify the proportion of class attendance, classroom questioning, classroom testing, video watching time and homework completion in the usual grades of online courses, and take random roll call to check the attendance and online learning of students in the teaching process. For more difficult oral topics, teachers should give enlightening and suggestive tips, gradually guide students to discuss, express ideas, so as to grasp the relevant contents. In the process of oral English practice, teachers should use various forms such as speech, news broadcast, retelling, group discussion, film dubbing, interview, debate, group report and other forms to stimulate students' desire to speak, and exercise their oral English ability. For the common problems in viewing and listening, teachers can take students' intensive listening materials in class, and lead students to understand by analyzing and explaining listening skills while listening together. With the help of the teacher, students are guided to find out the answers step by step, so as to train their listening comprehension, analytic thinking and reasoning ability. At the end of the class, teachers should guide and encourage students to make summary and reflection. Students can make self-evaluation or mutual evaluation. In this process, they should put forward suggestions to each other, make comprehensive evaluation according to the specific learning process and results, summarize the learning content, and stimulate the students' independent inquiry spirit and learning motivation, constantly consolidate the knowledge learned, and further improve the ability of English application and cooperation. For each class, teachers set aside appropriate time to sum up, change the model from "teacher-centered" to "studentcentered", pay more attention to the cultivation of students' language application ability and autonomous learning ability. This teaching mode actually embodies the humanistic education concept.

\subsection{After-class Teaching and Learning Activities}

After class, teachers can further supplement the corresponding courseware, reading materials, audio and video and other related content, so as to further broaden students' learning horizon and further deepen their understanding and mastery of relevant knowledge. Students can make full use of the network platform to achieve automatic scoring. Through a large number of online review materials, students can fully strengthen the learning effect, further increase the time and space of practice, so as to further expand the scope of knowledge, and more effectively complete the relevant learning tasks. 
After class consolidation practice module enables the specific classroom teaching to be fully extended, fully cultivate students' autonomous learning ability, and lay a solid foundation for their lifelong learning habits. [3]

In accordance with the teaching content of the online course, teachers also arrange the assignments on Dingtalk platform, clarify the submission time and requirements, take time to track and guide the students after class, communicate and interact with the students frequently, and give the students positive evaluation through the homework comments, so as to improve the students' learning enthusiasm. In addition to assigning homework after class, teachers should also guide students to further discuss interesting topics through learning platform, and encourage students to actively participate in online interactive topics to help students effectively consolidate and internalize knowledge. Students can not only exchange learning difficulties with other students through online discussion, but also use voice or video chat function of Dingtalk group to launch mobile English corner to practice oral English anytime and anywhere. Teachers should pay attention to the problems encountered in students' autonomous learning through the network platform, and provide timely help to ensure the effectiveness of students' offline learning.

\subsection{Exploration of Online Course Testing}

In the online course learning, the evaluation mode and online course form a good integration, which is not limited to the final result of students' online course learning, but combined with the progress of students' daily learning, learning frequency, online learning problem solving, online evaluation score, etc. [4] The online evaluation mode is formed through the statistics of a number of information. For example, after the completion of the unit learning task, teachers should collect all kinds of homework, audio and video files submitted by students on learning platform, consult their homework completion and learning situation (online participation, group cooperation and communication, discussion, learning attitude, personal speech) and other information, quantify and count all kinds of data, and give students comprehensive score through data analysis, so as to continuously improve students' enthusiasm for course learning. At the same time, it also helps teachers to have a more comprehensive understanding of all aspects of students, adjust teaching methods in time, and formulate effective teaching strategies. Moreover, in the general online courses, students learn in the form of micro class or MOOC, which have their own home page. Students can check the deficiencies in the score evaluation for review. If they get higher evaluation in the knowledge review, their scores can change in time, which also gives students more learning motivation and improves their learning initiative.

\section{REFLCETION ON COLLEGE ENGLISH ONLINE TEACHING AND LEARNING}

Under the background COVID-19, according to the guidance, Faculty of Foreign Languages makes of Huaiyin Institute of Technology full of MOOC resources of China University, the online course teaching resources of our university, Superstar online learning platform, Dingtalk platform, and Unipus platform to implement online English teaching. Due to the limitations of online teaching, teachers should listen to the feedback from other teachers, students and teaching management departments at any time in the teaching process, and constantly improve the online teaching. [5] If the Dingtalk platform is broken or stuck, the English Teaching and Research Office should have an emergency plan, which can use Wechat or QQ platform, and make supplementary adjustments to the teaching content according to the stuck time. Two weeks after the opening of the online course, the Faculty of Foreign Languages conducted an online questionnaire survey on the operation of teaching and the effect of online teaching. A total of 1000 students were given questionnaires. The survey shows that students are satisfied with college English online teaching, and the satisfaction rate is $79 \%$. Most of the students actively cooperate with the online teaching, attend class on time and complete the scheduled teaching content. Actually, not only students, teachers learn new skills, and complete the transformation of several roles as well.

First, teachers should be constant learners. Online courses are unfamiliar to most teachers. So teachers should learn a lot of new things such as, the platform selection, the establishment of flipped classroom, online teaching design, courseware production, the setting-up of online class group.

Second, teachers should provide high quality resources. During the pandemic period, various educational resource platforms provide learners with a large number of online resources. Teachers should strictly control the practicability and applicability of teaching resources, reintegrate teaching resources, and provide high-quality online learning resources for students. While applying the MOOC platform of China's universities as the source courses, we should design the classroom based on the learning strategies of learners, provide appropriate exercises and assignments, and ensure that the online teaching content is practical and applicable. Compared with the traditional college English teaching mode, the College English teaching mode based on various online learning platforms such as MOOC requires students to have stronger autonomous learning ability.[6]Teachers should help students realize the characteristics of online learning and make them aware of the importance of autonomous learning. Only in this way can students continuously adapt to various online college English learning platform and learn to choose appropriate learning strategies according to their learning motivation and learning style. 
Finally, teachers should be good companions during students' autonomous learning. Teachers should master the platform operation, conduct the integration of information technology and subject teaching, guide students to learn self-learning, transcend the classroom face-to-face situation presentation, explore the method of flipped learning, realize the interactive integration of virtual classroom. As a new thing, although online teaching and learning is hard, it is full of fun and creativity. Online learning is both strange and attractive to students. While they accept new things, they are constantly exploring their potential. From participating in live teaching to delivering audio and video homework, students' sense of gain and achievement is also constantly improving. In this process, teachers should take pains to correct students' homework, reply to students' questions and participate in the class discussion, becoming students' companion.

In a word, College English teaching based on online platform needs teachers to change their roles. Teachers should be the instructors and promoters of students' learning, mobilize students' enthusiasm and initiative in online learning, guide students to make clear teaching objectives, learning plans and learning tasks, and guide students to choose their own online learning strategies and methods. Although online resources are abundant, the leading position and guiding role of teachers cannot be ignored.

\section{CONCLUSION}

The Prevention and Control of COVID-19 Pandemic calls for the transformation of schools and teachers in the future. The organic integration of information technology and subject education provides teachers with more opportunities for scientific research, and also provides students with diversified learning platforms, thus changing the traditional education structure and mode and forming a new education mode. Online teaching not only provides new ideas and methods for English teaching, but also provides a good learning atmosphere for students. The self-study before class effectively increases the students' participation in the classroom and improves their autonomous learning ability; the tasks in and after class give full play to the students' subjectivity and enhance their ability of problem-solving, cooperative communication and team cooperation. College English learning on various online learning platforms is a very valuable learning experience for students. This learning experience cultivates students' autonomous learning ability and provides enlightenment and experience for college English teaching in the future. Teachers become the guidance for students to master and use learning strategies. Only when teachers and students work together can online teaching and learning quality be guaranteed. After the novel coronavirus pneumonia is over, the construction of online courses will usher in a new era. The function of online teaching platform will be more perfect. The online and offline blended teaching mode will also be widely promoted.

\section{REFERENCES}

[1] Li Ting-ting. Online Teaching Practice and Thinking of Higher Vocational College English during Prevention and Control of COVID-19 Pandemic[J]. Teaching of Forestry Region, 2020(06):66-68.

[2] Sun Shumei. Reform of College English Viewing, Listening and Speaking Based on Blended Teaching [J]. Modern Educational Technology, 2020(04):33-34.

[3] Wang Ping. Research on the Application of Online and Offline Mixed Mode in College English Teaching[J]. Science \& Technology Vision,2019(27):127-128.

[4] Yang Shanshan, Long Qiuju. Research on College English "Online and Offline" Blended Teaching Mode[J] . Journal of Baise University,2019(11):135-140.

[5] Liu Li. The Investigation on Learning Strategies of College English under the Background of "Novel Coronovirus Epidemic" [J]. Journal of Tonghua Normal University,2020(04):93-99.

[6] Wen Lijun. Research on the Informatization Reform of College English Teaching in the Era of Big Data[J]. Modern Educational Technology,2019(21):37-38. 